Article

\title{
Biological Responses of Onion-Shaped Carbon Nanoparticles
}

\author{
Jaehee Jang ${ }^{1,+}{ }^{,}$, Youngjun Kim ${ }^{2,+}$, Jangsun Hwang ${ }^{1}$, Yonghyun Choi ${ }^{1}$, Masayoshi Tanaka ${ }^{3} \mathbb{}$, \\ Eunah Kang ${ }^{2, *}$ and Jonghoon Choi ${ }^{1, * \text { (D) }}$ \\ 1 School of Integrative Engineering, Chung-Ang University, Seoul 06974, Korea \\ 2 School of Chemical Engineering \& Material Science, Chung-Ang University, Seoul 06974, Korea \\ 3 Department of Chemical Science and Engineering, Tokyo Institute of Technology, Tokyo 152-8550, Japan \\ * Correspondence: eakangek@cau.ac.kr (E.K.); nanomed@cau.ac.kr (J.C.); Tel.: +82-2-820-6684 (E.K.); \\ +82-2-820-5258 (J.C.) \\ + These authors contributed equally to this work.
}

Received: 4 June 2019; Accepted: 13 July 2019; Published: 15 July 2019

Abstract: Nanodiamonds are emerging as new nanoscale materials because of their chemical stability, excellent crystallinity, and unique optical properties. In this study, the structure of nanodiamonds was engineered to produce carbon nano-onion particles (CNOs) with multiple layers. Following a series of physicochemical characterizations of the CNOs, various evaluations for biological responses were conducted for potential biotechnological applications of the CNOs. The possibility of biological applications was first confirmed by assessment of toxicity to animal cells, evaluation of hemolysis reactions, and evaluation of reactive oxygen species. In addition, human immune cells were evaluated for any possible induction of an immune response by CNOs. Finally, the toxicity of CNOs to Escherichia coli present in the human colon was evaluated. CNOs have the chemical and physical properties to be a unique variety of carbon nanomaterials, and their toxicity to animal and human cells is sufficiently low that their biotechnological applications in the future are expected.

Keywords: carbon nanomaterial; nano-onion; biological properties; cytotoxicity; immune responses

\section{Introduction}

Nanomedicine is broadly defined as the biomedical application of nanotechnology. More specifically, nanomaterials with a variety of physical, chemical, and biological characteristics can be employed in biomedical applications to overcome difficulties that have remained unresolved. Recently, new therapeutic and diagnostic methods have been developed by combining simple supramolecular components using nanotechnology [1-5]. Examples include the detection of pathogenic antigens [6], diagnosis and imaging of disease [7], development of drug delivery vehicles [8-10], and development of antibacterial agents [11]. Carbon nanomaterials with various dimensions, such as one-dimensional carbon nanotubes, two-dimensional graphene, and zero-dimensional fullerenes, are very attractive nanomaterials. They have gained much attention and have been actively studied because of their small nanoscale size and various physicochemical characteristics that are due to the large surface-to-volume ratio. For example, applications in tissue engineering [12,13], drug or gene transfer biosensors [14], photothermal therapy [15], and antibacterial substances [16] are actively being pursued. Recently, carbon nanomaterials with various new structures, such as carbon dots or nanodiamonds, have been developed and are being continuously studied. However, some carbon nanomaterials have been reported to be toxic to certain cells or animals and to induce an immune response [17-19]. Carbon nanomaterials within the mammalian cell are reported to promote reactive oxygen species (ROS), which are the cause of the toxicity. The incidence and toxicity of ROS are known to vary 
depending on the type of carbon nanomaterial [20]. Therefore, a thorough evaluation of biocompatibility in the use of carbon nanomaterials in the field of nanomedicine is inevitable. Carbon nanomaterials such as graphene, graphene oxide, carbon nanotubes (CNTs), and acid functionalized CNTs have been studied for their potential toxicity and their cytotoxic mechanisms in cells for further biomedical applications. It was found that neat graphene was toxic when treated with a Raw 264.7 cell by inducing the production of reactive oxygen species and apoptosis [21] and the nanocomposite of metal and graphene can be applied as an electrochemical sensor, using excellent thermal conductivity and electric conductivity [22]. Graphene oxide is involved in the release of lactate dehydrogenase (LDH) released from dead or damaged cells by apoptosis or necrosis and causing toxicity, due to the accumulation of autophagosome [23]. There are many applications for the application of graphene oxide, but, for example, there is a case applied to photodynamic therapy (PDT). By directly coupling the polyethylene glycol (PEG) with functional groups on the graphene oxide sheet, the dispersibility of the existing graphene oxide was further improved. Furthermore, branched polyethyleneimine (BPEI) was conjugated using EDC-NHS coupling. BPEI increased the loading capability of Chlorin e6 (Ce6), a photosensitizer, and increased photodynamic efficacy [24]. In addition, single-walled carbon nanotubes (SWCNTs) have been shown to cause damage to mitochondria [25], and the acid functionalized SWCNTs were also found to be involved in LDH release and accumulation in the autophagosome, leading to toxicity. [23]. Multi-walled carbon nanotubes (MWCNTs) likewise have been shown to induce apoptosis, the release of LDH [26], and mitochondrial damage [27]. The toxicity of SWCNTs, MWCNTs, and acid functionalized MWCNTs to intestinal microbes was evaluated and found to be antimicrobial. All of these can be applied as antimicrobial agents and CNTs have been reported to exhibit antibacterial effects by destroying the cell walls and membranes of bacteria [28]. Furthermore, carbon nanomaterials are used as a genosensor [29], drug delivery carrier [30], and biosensor [31]. Table 1 summarizes carbon materials for their main biological applications and toxicity.

Table 1. Toxicity and application of carbon nanomaterials.

\begin{tabular}{|c|c|c|c|c|}
\hline Nanomaterial & Target Cell & Effect in Cells & Application & Ref. \\
\hline Neat graphene & RAW 264.7 & $\begin{array}{l}\text { ROS generation, } \\
\text { apoptosis induction }\end{array}$ & $\begin{array}{l}\text { Electrochemical } \\
\text { sensing }\end{array}$ & {$[21,22]$} \\
\hline $\begin{array}{c}\text { Graphene oxides } \\
\text { (GO) }\end{array}$ & $\begin{array}{c}\text { Peritoneal } \\
\text { macrophages }\end{array}$ & $\begin{array}{l}\text { LDH release, } \\
\text { Autophagosome } \\
\text { accumulation, }\end{array}$ & $\begin{array}{l}\text { Photodynamic } \\
\text { therapy (PDT) }\end{array}$ & {$[23,24]$} \\
\hline SWCNTs & $\begin{array}{l}\text { Mouse peritoneal } \\
\text { macrophages }\end{array}$ & Mitochondrial damage & $\begin{array}{l}\text { Antibacterial } \\
\text { material }\end{array}$ & {$[25,28]$} \\
\hline $\begin{array}{c}\text { Acid } \\
\text { functionalized } \\
\text { SWCNTs }\end{array}$ & $\begin{array}{c}\text { Peritoneal } \\
\text { macrophages }\end{array}$ & $\begin{array}{l}\text { LDH release, } \\
\text { Autophagosome } \\
\text { accumulation }\end{array}$ & $\begin{array}{l}\text { Drug delivery } \\
\text { carrier }\end{array}$ & {$[23,30]$} \\
\hline MWCNTs & RAW264.7, A549 & $\begin{array}{l}\text { LDH release and } \\
\text { oxidative stress }\end{array}$ & Genosensor & {$[26,29]$} \\
\hline $\begin{array}{c}\text { Acid } \\
\text { functionalized } \\
\text { MWCNTs }\end{array}$ & RAW 264.7 & $\begin{array}{l}\text { Apoptosis via the } \\
\text { mitochondrial } \\
\text { pathway }\end{array}$ & Biosensor & {$[27,31]$} \\
\hline
\end{tabular}

Previous studies on properties and toxicity of carbon nano-onions (CNOs) have been carried out. A team of researchers studied surface functionalization to improve the problems of existing CNOs [32,33]. The other team evaluated the derivatives of $\mathrm{CNO}$ against Hydra vulgaris [34], providing a model system for the application of anti-microbial carbon nanomaterials. In this study, we synthesized CNOs (multi-walled fullerenes) using nanodiamonds. In addition, carboxyl groups were introduced on the surface of $\mathrm{CNO}$ to increase the water dispersion of the nanomaterials, which is essential for their biomedical applications. We investigated the feasibility of biomedical applications of CNOs by analyzing their physicochemical characteristics and biological responses. We evaluated whether CNO is a biocompatible carbon nanomaterial by performing assessments of $\mathrm{CNO}$ cytotoxicity to human 
dermal fibroblast (HDF) cells and peripheral blood mononuclear cells (PBMCs), immune response assays, hemolysis evaluations, assays for ROS generation (which is the main toxic factor of carbon nanomaterials), and measurement of toxicity to Escherichia coli intestinal bacteria. In conclusion, CNO showed no toxicity to HDF cells and PBMCs and did not induce the secretion of IL-2 and tumor necrosis factor-alpha (TNF-alpha) (which are cytokines in human immune cells). Moreover, the hemolysis rate tended to be very low, and CNO was not toxic to E. coli. Particularly because of the low occurrence of ROS, CNO is considered promising for use as a new carbon nanomaterial in research in various biomedical fields, such as tissue engineering, drug delivery systems, and biosensors.

\section{Materials and Methods}

\subsection{Pyrolysis of Nanodiamond}

Carbon nano-onions (CNOs) were generated by the pyrolysis of nanodiamonds (NDs) (Plasma Chem, Berlin, Germany) at high temperature. A crucible of ND (3 g of gray powder) was placed in a furnace tube and annealed at $1400{ }^{\circ} \mathrm{C}$ for $1 \mathrm{~h}$ under a nitrogen purge. The temperature was gradually lowered to room temperature under nitrogen. The NOs obtained in this annealing process were entirely black.

\subsection{Carboxylated Nano-Onion}

The surface of the CNO treated by pyrolysis was functionalized with carboxyl groups by the Hummers' method [35] to create $\mathrm{CNO}-\mathrm{COOH}$, as shown in Figure 1. Sulfuric acid (360 mL) and phosphoric acid $(40 \mathrm{~mL})$ were carefully added to a round bottom flask in an ice bath. $\mathrm{CNO}(3 \mathrm{~g})$ and potassium permanganate $(9 \mathrm{~g})$ were added into the sufficiently cooled sulfuric acid/phosphoric acid solution. The $\mathrm{CNO}$ was homogeneously dispersed for $1 \mathrm{~h}$ using a bath sonicator. The $\mathrm{CNO}$ dispersion was oxidized with gentle stirring at $50{ }^{\circ} \mathrm{C}$. After $12 \mathrm{~h}, 800 \mathrm{~mL}$ of deionized (DI) water was added to the dispersion; the mixture was cooled and then combined with hydroperoxide $(3 \mathrm{~mL})$ to stop reactivity. The mixture was vacuum-filtered using a $0.2 \mu \mathrm{m}$ polytetrafluoroethylene (PTFE) hydrophilic membrane filter (SciLab, Seoul, Korea). The filtered compact cake was washed twice with DI water (200 mL), $\mathrm{HCl}(200 \mathrm{~mL})$, and ethanol $(200 \mathrm{~mL})$ through vacuum filtration. Finally, after washing with diethyl ether $(200 \mathrm{~mL})$, the cake was dried overnight in an $80^{\circ} \mathrm{C}$ air-circulating oven.

\subsection{Characterization}

X-ray photoelectron spectroscopy (XPS) measurements were performed with a K-alpha+ spectrometer (Thermo Fisher Scientific, Waltham, MA, USA), using an Al K $\alpha$ energy source. The spectra were analyzed using Advantage software. Transmission electron microscopy (TEM) images were acquired using a JEM-2100F electron microscope (JEOL, Tokyo, Japan). The CNO dispersion was dropped onto a Lacey Formvar/Carbon 200-mesh grid (Ted Pella, Redding, CA, USA) and dried for $10 \mathrm{~min}$ in a $60^{\circ} \mathrm{C}$ oven. $\mathrm{CNO}$ and $\mathrm{CNO}-\mathrm{COOH}(1 \mathrm{mg})$ were dispersed in ethanol $(1 \mathrm{~mL})$ and diluted with an appropriated concentration for the images.

\subsection{Cell Viability Assay}

Cell viability was determined using a CCK-8 cell counting kit [36] (Dojindo Molecular Technology, Kumamoto, Japan). Cells were seeded with equal density into each well of 96 -well plates $\left(5 \times 10^{3}\right.$ cells per well), using $100 \mu \mathrm{L}$ of cell culture medium (low-glucose Dulbecco's Modified Eagle Medium (DMEM), supplemented with $10 \%$ (v/v) fetal bovine serum and $1 \%$ sterile antibiotic), and were incubated for $24 \mathrm{~h}$ at $37^{\circ} \mathrm{C}$. Cells were then treated in 96-well plates with varying concentrations of $\mathrm{CNO}$ and $\mathrm{CNO}-\mathrm{COOH}$ particles in a serum-free medium for $24 \mathrm{~h}$ at $37^{\circ} \mathrm{C}$. Untreated cells served as a control group. At the end of the treatment, CCK- 8 dye was added to each well, and the plates were incubated for another $2 \mathrm{~h}$ at $37^{\circ} \mathrm{C}$. To prevent particles from interfering with this assay, the solution in each well of each plate was quantitatively transferred to an empty well in another plate after 
centrifugation. Subsequently, the absorbance was measured at $450 \mathrm{~nm}$, using a microplate reader. Each treatment was repeated three times. The cell viability with the $\mathrm{CNO}$ and $\mathrm{CNO}-\mathrm{COOH}$ was further assessed using a LIVE/DEAD ${ }^{\circledR}$ Viability/Cytotoxicity Kit (Invitrogen ${ }^{\mathrm{TM}}$; Life Technologies, Carlsbad, CA, USA). The kit can quickly discriminate live from dead cells by simultaneously staining with green-fluorescent calcein acetoxymethyl ester to indicate intracellular esterase activity and with red-fluorescent ethidium homodimer-1 to indicate loss of plasma membrane integrity. After $24 \mathrm{~h}$ of incubation with varying concentrations of $\mathrm{CNO}$ and $\mathrm{CNO}-\mathrm{COOH}$, the culture medium was removed. Next, $200 \mu \mathrm{L}$ of LIVE/DEAD stain was added to each well, and the wells were incubated for $30 \mathrm{~min}$ at $37^{\circ} \mathrm{C}$. Finally, the samples were observed using a fluorescence microscope.

A

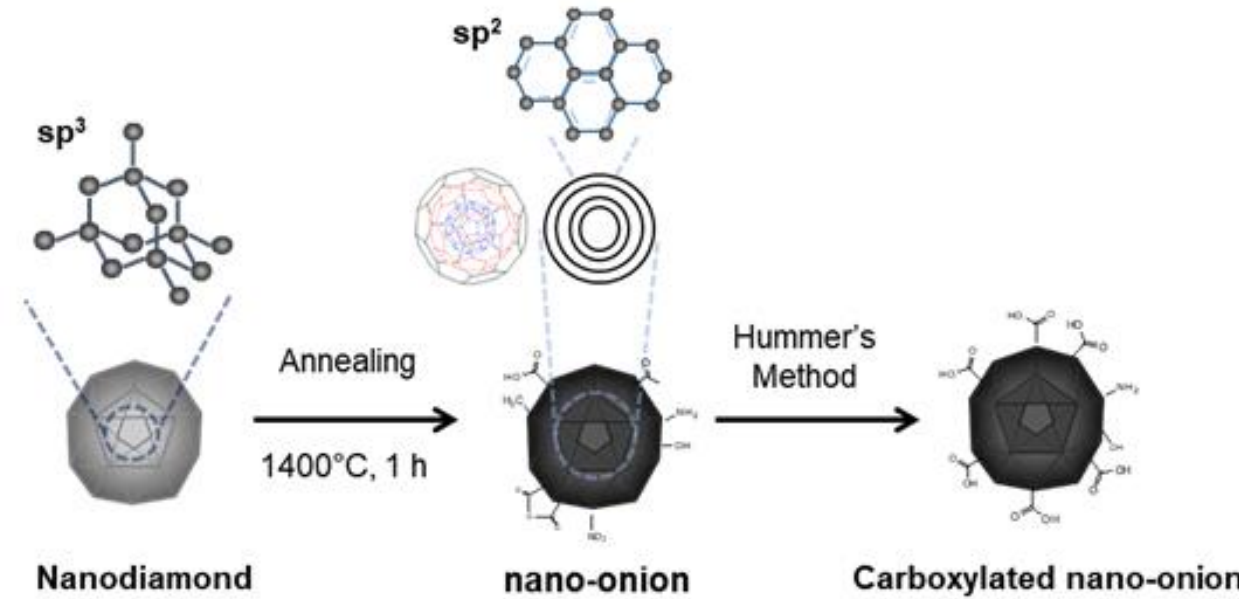

B
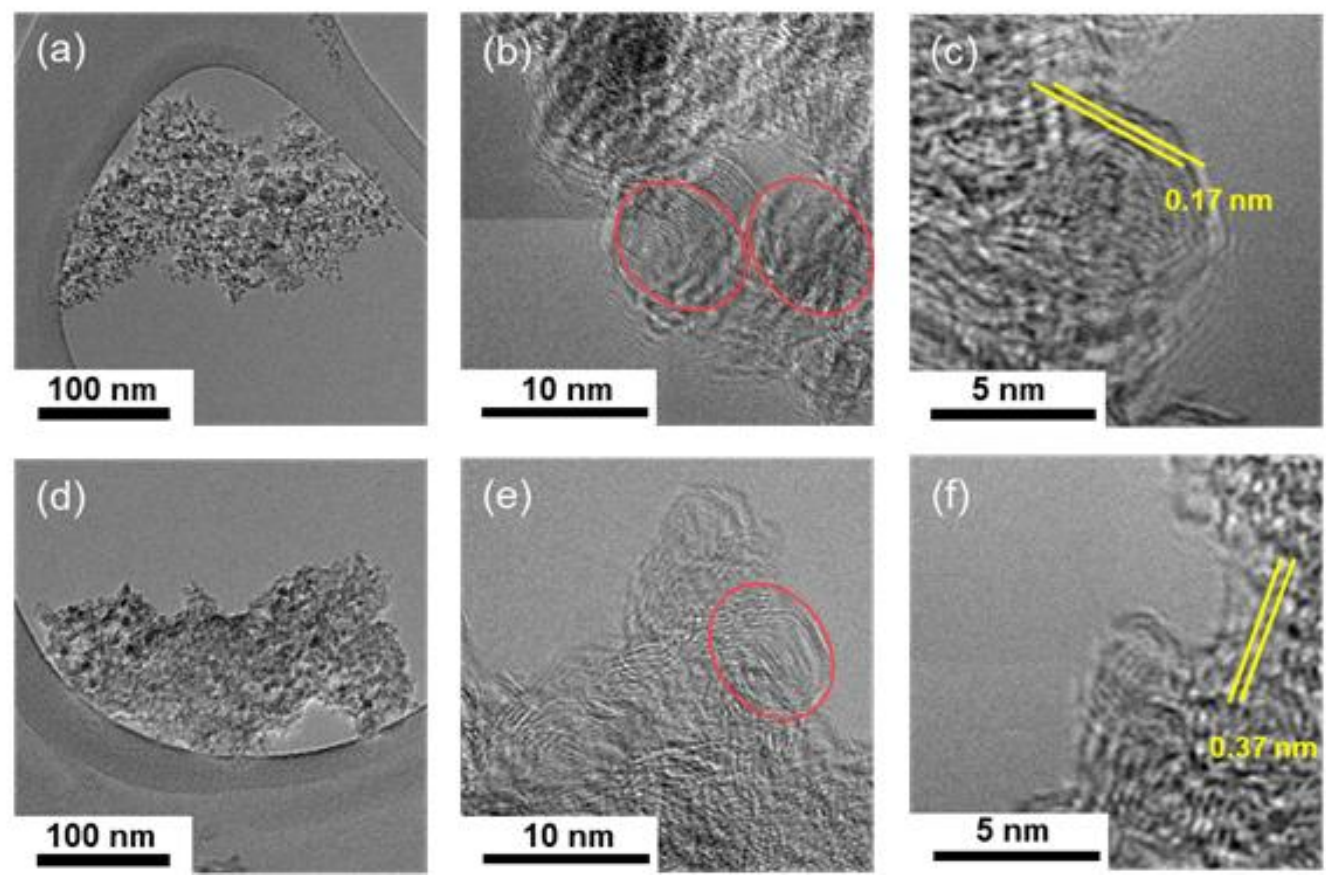

Figure 1. (A) Schematic drawing of structural changes from nanodiamond into carbon nano-onion particles $(\mathrm{CNO})$ by pyrolysis and into $\mathrm{CNO}-\mathrm{COOH}$ by Hummers' method; $(\mathrm{B}(\mathrm{a}-\mathrm{c})$ ) Transmission electron microscopy (TEM) images of $\mathrm{CNO}$, and $(\mathrm{B}(\mathrm{d}-\mathrm{f})) \mathrm{CNO}-\mathrm{COOH}$. The crystalline lattice gap of the onion-like layer is present in both $\mathrm{CNO}(\mathrm{B}(\mathrm{c}))$ and $\mathrm{CNO}-\mathrm{COOH}(\mathrm{B}(\mathrm{f}))$, yellow bars showing the gap between lattices. 


\subsection{Hemolysis Test}

Aliquots ( $1 \mathrm{~mL}$ ) of $2 \%$ red blood cells (from sheep blood) suspended in phosphate-buffered saline (PBS) were mixed with $\mathrm{CNO}$ and $\mathrm{CNO}-\mathrm{COOH}$ solution (final concentrations of $\mathrm{CNO}$ and $\mathrm{CNO}-\mathrm{COOH}$ were $5000,10,000,50,000$, and $100,000 \mathrm{ng} / \mathrm{mL}$ each) and incubated at $37^{\circ} \mathrm{C}$ for $1 \mathrm{~h}$. The samples were then centrifuged at $2000 \mathrm{rpm}$ for $5 \mathrm{~min}$ to remove intact red blood cells, and the absorbance of the supernatant was measured at $545 \mathrm{~nm}$ for the release of hemoglobin. PBS and 5\% Triton X-100 were used as a negative and positive control, respectively. All measurements were performed in triplicate, and the hemolysis rate $(\%)$ was determined as $\mathrm{HR}(\%)=\left(\mathrm{OD}_{\text {sample }}-\mathrm{OD}_{\text {negative control }}\right) /\left(\mathrm{OD}_{\text {positive control }}\right.$ $\left.-\mathrm{OD}_{\text {negative control }}\right) \times 100 \%$ [37].

\subsection{Intracellular Reactive Oxygen Species Measurement}

The intracellular ROS was determined using a well-characterized probe, namely $2^{\prime}, 7^{\prime}$-dichlorofluorescein diacetate (DCFH-DA) [38]. DCFH-DA passively enters the cell and is hydrolyzed by esterases to DCFH. This nonfluorescent molecule is then oxidized to the fluorescent compound dichlorofluorescein (DCF) by cellular oxidants. A $10 \mathrm{mM}$ DCFH-DA stock solution (in methanol) was diluted 1000-fold in the cell culture medium without serum or other additives to yield a $10 \mathrm{mM}$ working solution. Cells were washed twice with PBS and then incubated with DCFH-DA working solution for $20 \mathrm{~min}$ in a dark environment $\left(37^{\circ} \mathrm{C}\right.$ incubator). This was followed by treatment with varying concentrations of $\mathrm{CNO}$ and $\mathrm{CNO}-\mathrm{COOH}$ particles for $24 \mathrm{~h}$. The cells were then washed three times with PBS to eliminate DCFH-DA that did not enter the cells. Cells were collected in suspension and the fluorescence was determined at $488 \mathrm{~nm}$ excitation and $525 \mathrm{~nm}$ emission, using a fluorescence spectrophotometer.

\subsection{Cytokine Profiling Assay}

The cytokine profiling was performed using the enzyme-linked immunosorbent assay (ELISA) [39]. An unlabeled capture antibody was diluted to a final concentration of $0.5-8 \mu \mathrm{g} / \mathrm{mL}$ in coating buffer (Cat. No. 421701, BioLegend, CA USA) and $100 \mu \mathrm{L}$ were transferred to each well of a high-affinity, protein-binding ELISA plate (for example BioLegend Cat. No. 423501). The plate was incubated at $4{ }^{\circ} \mathrm{C}$ overnight. After three washes with PBS/Tween, non-specific binding sites were blocked by adding $200 \mu \mathrm{L}$ of blocking solution to each well. The plate was incubated at room temperature for $1 \mathrm{~h}$. After three additional washes with PBS/Tween, $100 \mathrm{~mL}$ of the supernatant of cells treated with varying concentrations of $\mathrm{CNO}$ and $\mathrm{CNO}-\mathrm{COOH}$ particles was added to each well in the ELISA plate and incubated at room temperature for 2-4 hours. After another three washes with PBS/Tween, $100 \mathrm{~mL}$ of biotin-labeled detection antibody, diluted to a concentration of $0.25-2 \mu \mathrm{g} / \mathrm{mL}$ in blocking solution, was added to each well and incubated at room temperature for $1 \mathrm{~h}$. After another three washes with PBS/Tween, $100 \mathrm{~mL}$ of Av-HRP conjugate (BioLegend Cat. No. 405103) at its predetermined optimal concentration in blocking buffer (usually between 1/500 and 1/2000) was added to each well. After incubation and washing, $100 \mathrm{~mL}$ of TMB Reagent was transferred to each well and incubated at room temperature for color development. The optical density (OD) of each well was read with a microplate reader at $450 \mathrm{~nm}$ wavelength.

\subsection{Bacterial Tests}

The in vitro bacterial activities of $\mathrm{CNO}$ and $\mathrm{CNO}-\mathrm{COOH}$ were examined using the colony counting method [40]. Gram-negative E. coli (ATCC 25922) were used as microorganisms. Sterilized Luria-Bertani (LB) broth was measured $(1 \mathrm{~mL})$ into sterile tubes. The $\mathrm{CNO}$ and $\mathrm{CNO}-\mathrm{COOH}$ at varying concentrations $(1.5625,3.125,6.25,12.5,25$, and $50 \mu \mathrm{g} / \mathrm{mL})$ were introduced into the LB broth solution, which contained approximately $1.5 \times 10^{5}$ colony forming units (CFU) of E. coli. The mixtures were cultured at $37^{\circ} \mathrm{C}$ in a shaking incubator for $12 \mathrm{~h}$. Pure PBS buffer and antibiotics were also tested as a negative control and positive control, respectively. A $100 \mu \mathrm{L}$ aliquot of each of these cell solutions was seeded onto LB 
agar using a surface spread plate technique. The plates were incubated at $37^{\circ} \mathrm{C}$ for $24 \mathrm{~h}$. The bacterial CFUs were then counted to calculate the survivors.

\subsection{Statistical Analysis}

A one-tailed Mann-Whitney U test was performed using GraphPad Prism (v 7 for Mac OS X; GraphPad Software, La Jolla, CA, USA).

\section{Results and Discussion}

In this study, the $\mathrm{sp}^{3}$ structure nanodiamond was annealed at $1400{ }^{\circ} \mathrm{C}$ for $1 \mathrm{~h}$, and then the $\mathrm{sp}^{2}$ structure $\mathrm{CNO}$ was synthesized. The $\mathrm{CNO}-\mathrm{COOH}$ was subsequently synthesized by Hummers' method (Figure 1A). The TEM images of $\mathrm{CNO}$ and $\mathrm{CNO}-\mathrm{COOH}$ showed visualized features and the lattice gap between molecular layers, as shown in Figure 1B. Both $\mathrm{CNO}$ and $\mathrm{CNO}-\mathrm{COOH}$ show the amorphous onion-like layers, unlike the crystalline structure of the nanodiamond. CNOs exist as aggregated forms between 300 and $400 \mathrm{~nm}$, while each CNO is 5-8 nm. High-magnification TEM images of $\mathrm{CNO}$ and $\mathrm{CNO}-\mathrm{COOH}$ show lattice gaps of $0.17 \mathrm{~nm}$ and $0.37 \mathrm{~nm}$, respectively. The greater spacing in the lattice compared to the crystal has the potential to serve as a reservoir for electrons or small-molecule drugs. Two-dimensional graphene is believed to complex with small molecules via phi-phi stacking or physical adsorption, as small molecules settle in the interface between sheets.

The XPS spectra of the $\mathrm{C} 1 \mathrm{~s}$ and $\mathrm{O} 1 \mathrm{~s}$ peaks of the $\mathrm{CNO}$ and $\mathrm{CNO}-\mathrm{COOH}$ are shown in Supplementary Materials Figure S1A. CNO consists mainly of carbon (the 97.96\%) and has low contents of oxygen $(1.47 \%)$ and nitrogen $(0.57 \%)$. In contrast, a $\mathrm{CNO}-\mathrm{COOH}$ has high oxygen content $(19.16 \%)$, with $80.13 \%$ carbon and $0.71 \%$ nitrogen. A simple comparison shows that the oxygen content increased 13-fold in the transformation of $\mathrm{CNO}$ into $\mathrm{CNO}-\mathrm{COOH}$, indicating that oxidation by the Hummer's method was functionalized into the carboxylation of the onion surface (Supplementary Materials Figures S1 and S2 and Supplementary Materials Table S1). The O1s peaks of the CNO and $\mathrm{CNO}-\mathrm{COOH}$ were deconvoluted into three components at $531.6 \mathrm{eV}(\mathrm{C}=\mathrm{O})$ and $533.1 \mathrm{eV}(\mathrm{C}-\mathrm{OH}$ and $\mathrm{C}-\mathrm{O}-\mathrm{C}$ ). Based on the O1s peak, the relative $\mathrm{C}=\mathrm{O}$ contents were 19.9 and $26.9 \%$ for the $\mathrm{CNO}$ and $\mathrm{CNO}-\mathrm{COOH}$, respectively (Supplementary Materials Table S2). The amplification of the $\mathrm{C}=\mathrm{O}$ carbonyl group content and oxygen content indicates that the carboxyl group was successfully functionalized on the $\mathrm{CNO}$ surface. The $\mathrm{C} 1 \mathrm{~s}$ peaks of the $\mathrm{CNO}$ and $\mathrm{CNO}-\mathrm{COOH}$ were deconvoluted into six component peaks at $284.6(-\mathrm{C}=\mathrm{C}-)$, $285.4(-\mathrm{C}-\mathrm{C}-), 286.0(\mathrm{C}-\mathrm{O}), 287.2(\mathrm{C}=\mathrm{O}), 289(-\mathrm{COO}-)$, and $290.55 \mathrm{eV}\left(\pi-\pi^{*}\right)$. The relative contents of $-\mathrm{C}=\mathrm{C}-$, which present an amorphous onion-like sp2 layer, were similar $(54.0 \%$ and $49.7 \%$ ) for the $\mathrm{CNO}$ and $\mathrm{CNO}-\mathrm{COOH}$. In contrast, the relative contents of $-\mathrm{C}=\mathrm{O}-$ and $-\mathrm{COO}-$ were 18.13 and $9.66 \%$, respectively, for the $\mathrm{CNO}-\mathrm{COOH}$, showing the high carboxylate content on the CNO surface.

HDF cells and human PBMCs, which are composed of lymphocytes (for example T cells, B cells, and NK cells) and monocytes, were used to determine the biocompatibility of $\mathrm{CNO}$ and $\mathrm{CNO}-\mathrm{COOH}$ (Figure 2). Cytotoxicity tests were performed by using the CCK-8 assay after $24 \mathrm{~h}$ of sample treatment with different concentrations (namely 100, 500, 1000, 5000, and 10,000 ng/mL). For the negative control, the basal medium without any nanoparticle sample was added to the cells. As a positive control, Triton X-100 was used, which is known to dissolve the cell membrane as a surfactant and to kill the cell. Results show that cell viability of the $\mathrm{CNO}$ treatment group is high at all concentrations, whereas $\mathrm{CNO}-\mathrm{COOH}$ decreases the cell viability to $80 \%$ at particle concentrations higher than $1000 \mathrm{ng} / \mathrm{mL}$ (Supplementary Materials Figure S3A). In the image analyses of the HDF cells, an increased number of aggregated $\mathrm{CNO}$ particles are observed compared with $\mathrm{CNO}-\mathrm{COOH}$, because the number of ionizable functional groups are lower in $\mathrm{CNO}$. Particle aggregation and hydrophobicity would be the primary reasons for $\mathrm{CNO}$ having lower toxicity than $\mathrm{CNO}-\mathrm{COOH}$ at the same concentration when co-cultured with cells. This phenomenon is also common in other carbon nanomaterials. In a previous report [41], a comparison of the toxicity of reduced graphene oxide with that of a neat graphene oxide showed that the reduced graphene oxide, which has better solubility in an aqueous environment, was highly 
toxic. The cell viability test with PBMC also showed no toxicity with either $\mathrm{CNO}$ or $\mathrm{CNO}-\mathrm{COOH}$ at any concentration (Supplementary Materials Figure S3B). It should also be noted that $\mathrm{CNO}$ is present as an aggregate due to lack of oxygen function and is larger than $\mathrm{CNO}-\mathrm{COOH}$. $\mathrm{CNO}-\mathrm{COOH}$ has excellent dispersibility due to its large number of oxygen functional groups. As $\mathrm{CNO}-\mathrm{COOH}$ exists as individual particles, it has a large surface area to contact with cells and is more cytotoxic than CNO.

A

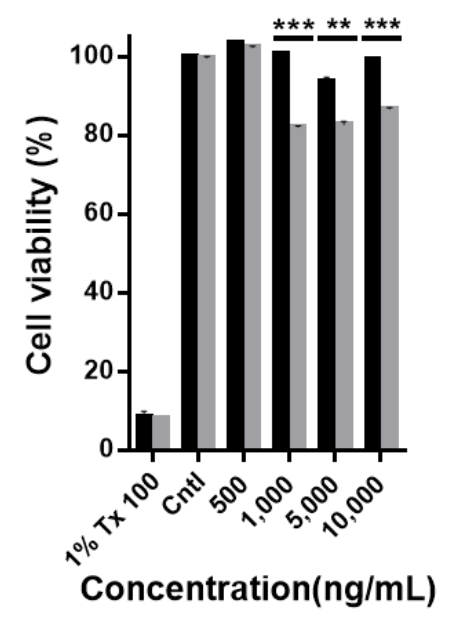

B

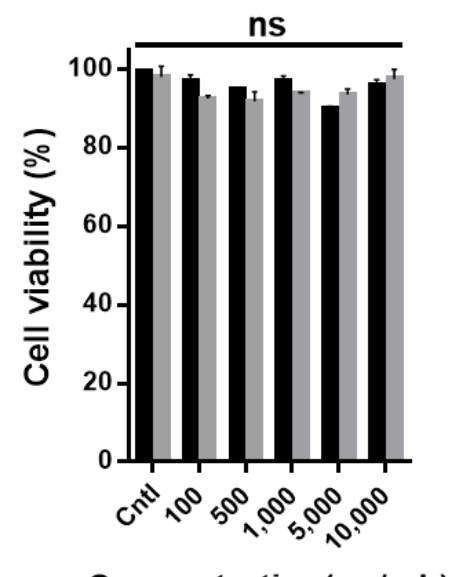

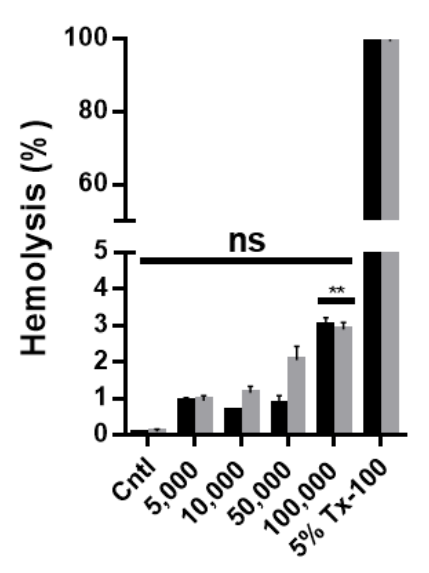

Concentration $(\mathrm{ng} / \mathrm{mL})$

Figure 2. Cytotoxicity test of $\mathrm{CNO}$ (black bar) and $\mathrm{CNO}-\mathrm{COOH}$ (gray bar) on human dermal fibroblast (HDF) cells and peripheral blood mononuclear cells (PBMCs). CCK-8 assay of treated samples incubated with varying concentrations $(100,500,1000,5000$, and 10,000 ng/mL) of CNO and CNO-COOH with (A) HDF cells, and (B) PBMCs; (C) percent hemolysis of red blood cells incubated with varying concentrations $(5000,10,000,50,000$, and $100,000 \mathrm{ng} / \mathrm{mL})$ of $\mathrm{CNO}$ and $\mathrm{CNO}-\mathrm{COOH}$.

Hemolysis, an important consideration for the blood compatibility of nanoparticles, was tested with both $\mathrm{CNO}$ and $\mathrm{CNO}-\mathrm{COOH}$ by co-culturing them with red blood cells. The test consisted of measuring the concentration of hemoglobin leaking out of red blood cells because of the collapse of the red blood cells. As shown in Figure $2 \mathrm{C}$, both $\mathrm{CNO}$ and $\mathrm{CNO}-\mathrm{COOH}$ tended to increase the rate of hemolysis in proportion to their concentrations, but showed a hemolysis rate of less than $4 \%$, even at a very high particle concentration of $100,000 \mathrm{ng} / \mathrm{mL}$.

ROSs are highly reactive molecules containing oxygen ions and hydrogen peroxide. Oxidative stresses, due to their high reactivity, can damage the cell structure. ROS generation caused by the presence of carbon-based nanomaterials is one of the major causes of induced cell cytotoxicity. Therefore, the quantity of ROS produced at various concentrations $(500,1000,5000$, and 10,000 ng/mL) of $\mathrm{CNO}$ and $\mathrm{CNO}-\mathrm{COOH}$ was investigated (Figure 3). The negative control was treated with a neat basal medium, and the positive control was treated with hydrogen peroxide as reactive oxygen species. The results show that a substantial quantity of ROS was detected in the positive group treated with hydrogen peroxide, and no significant differences were found among the $\mathrm{CNO}, \mathrm{CNO}-\mathrm{COOH}$, and control group; however, the ROS production decreased slightly with increasing concentrations of 500 to $\sim 10,000 \mathrm{ng} / \mathrm{mL}$. The quantity of ROS was reduced as the particle concentration increased because the quantities of $\mathrm{CNO}$ and $\mathrm{CNO}-\mathrm{COOH}$ internalized in the cells also increased. $\mathrm{CNO}$ and $\mathrm{CNO}-\mathrm{COOH}$ taken up in the cell would interfere with the ROS assay, quenching the fluorescence signal of ROS. This trend is more significant with $\mathrm{CNO}-\mathrm{COOH}$ because of its excellent solubility and efficient cell penetration. It should be noted that the current assay results are correct for the $\mathrm{CNO}$ functionalized by Hummers' method, having $\mathrm{COOH}, \mathrm{CHO}$, or $\mathrm{C}=\mathrm{O}$ groups due to the oxidation processes. The ROS results here may not be generalized for all functionalized CNO. 
A

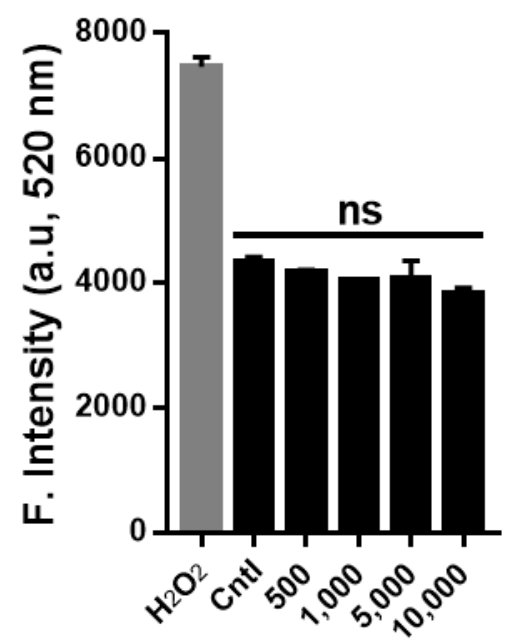

Concentration(ng/mL)
B

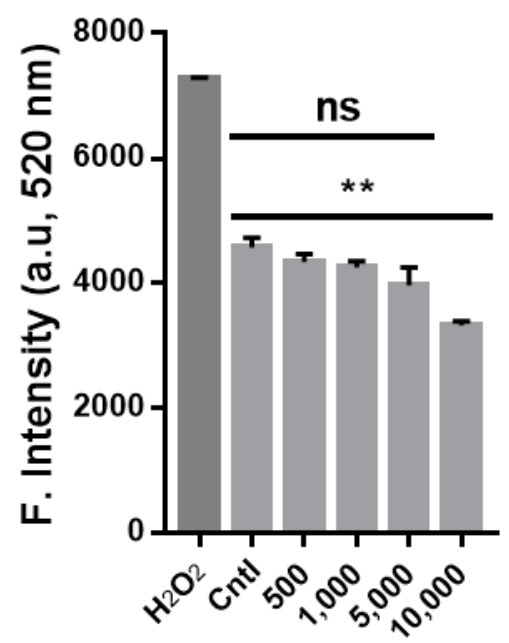

Concentration $(\mathrm{ng} / \mathrm{mL})$

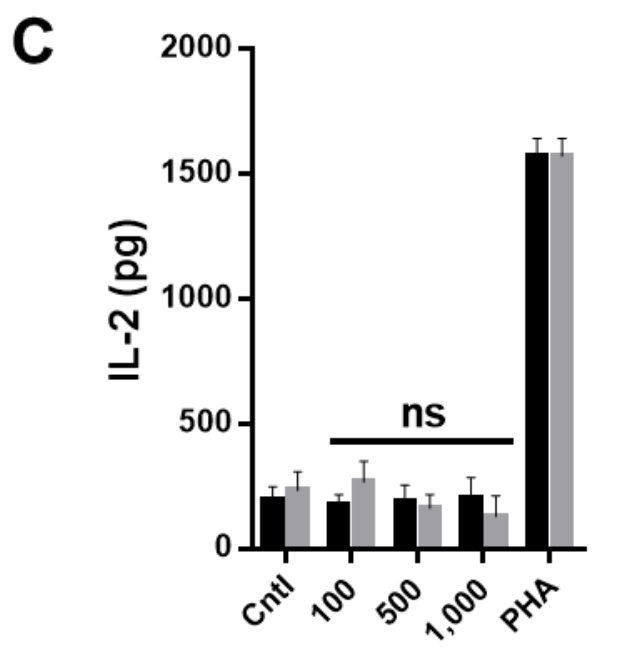

Concentration $(\mathrm{ng} / \mathrm{mL})$
D

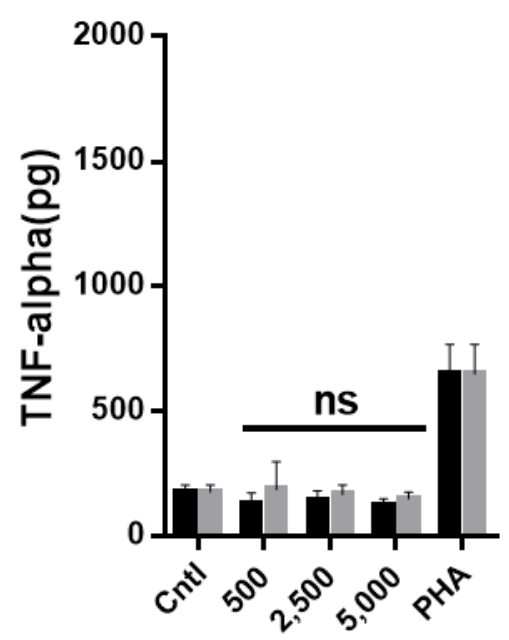

Concentration $(\mathrm{ng} / \mathrm{mL})$

Figure 3. Fluorescence intensity according to the quantity of reactive oxygen species (ROS) of DCFDA $\left(2^{\prime}, 7^{\prime}\right.$-dichlorofluorescin diacetate) on HDF cells after sample treatment with varying concentrations (500, 1000,5000 , and 10,000 ng/mL) for (A) CNO (black bar), and (B) CNO-COOH (gray bar); (C) production of IL-2 after sample treatment on PBMCs with varying concentrations (100, 500, and $1000 \mathrm{ng} / \mathrm{mL})$; (D) production of tumor necrosis factor-alpha (TNF-alpha) after sample treatment on PBMCs with varying concentrations $(500,2500$, and $5000 \mathrm{ng} / \mathrm{mL}$ ).

The T cells in PBMCs secrete cytokines, induce proliferation of macrophages, and promote immune cell differentiation. To investigate the immunological responses of $\mathrm{T}$ cells possibly induced by $\mathrm{CNO}$ and $\mathrm{CNO}-\mathrm{COOH}$, the levels of interleukin-2 (IL-2) and tumor necrosis factor-alpha (TNF-alpha) secreted by the PBMCs were assayed using ELISA, with varying concentrations of $\mathrm{CNO}$ and $\mathrm{CNO}-\mathrm{COOH}$ (Figure $3 \mathrm{C}-\mathrm{D}$ ). The results indicate that the quantity of IL-2 secreted by $\mathrm{CNO}$ and $\mathrm{CNO}-\mathrm{COOH}$ was less than $500 \mathrm{pg}$ in the negative control and at all concentrations of $\mathrm{CNO}$ and $\mathrm{CNO}-\mathrm{COOH}$. In addition, the quantity of TNF-alpha secreted was less than $200 \mathrm{pg}$ in the negative control and at all concentrations of $\mathrm{CNO}$ and $\mathrm{CNO}-\mathrm{COOH}$. Therefore, $\mathrm{CNO}$ and $\mathrm{CNO}-\mathrm{COOH}$ are negligibly toxic to human cells and non-immunogenic and are potentially biocompatible nanomaterials. 
There are approximately 100 trillion microorganisms in the human body called human microbiota; this number is ten times higher than the number of human cells and includes both beneficial and harmful bacteria. These microorganisms are present in various parts of the body, such as the skin, oral cavity, genitalia, respiratory tract, and gastrointestinal tract. The gastrointestinal tract has the most numerous and greatest variety of microorganisms. The significant role that microorganisms play in interactions with the human body, such as absorption and metabolism of nutrients in the human body, maturation, development of the immune system and nervous system, and the occurrence and prevention of various diseases, is well documented. An upset in the balance between beneficial and harmful bacteria could lead to multiple diseases, such as obesity, diabetes, and colorectal cancer [42-44]. To test the cytotoxicity of $\mathrm{CNO}$ and $\mathrm{CNO}-\mathrm{COOH}$ against microorganisms, E. coli was chosen as a model in our evaluation. The negative control was supplemented with the no-treatment medium, whereas the positive control was given an antibiotic-antimycotic. The test results showed that all the bacteria were killed in the positive control with antibiotics, but there was no difference between the negative control and $\mathrm{CNO}$ and $\mathrm{CNO}-\mathrm{COOH}$, even at their highest concentration of 50,000 ng/mL, and they did not affect the E. coli (Figure 4).
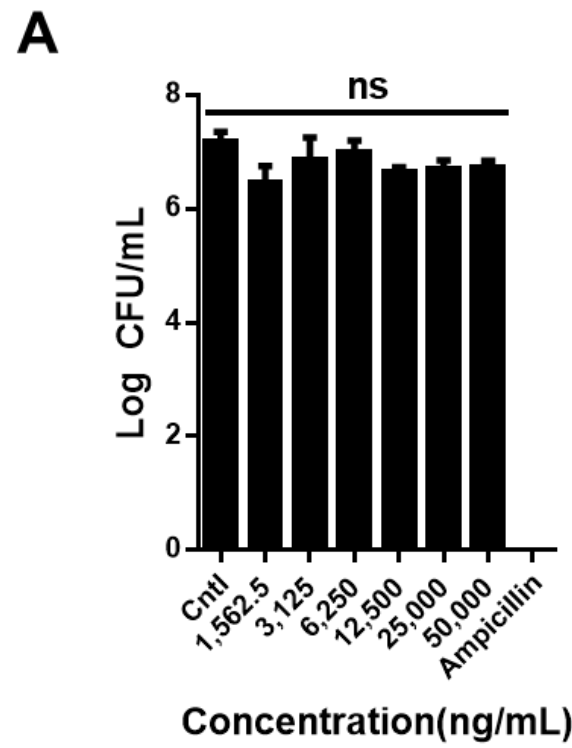

B

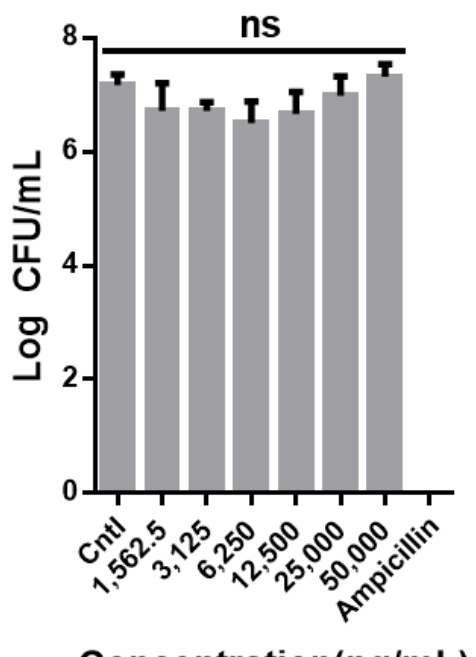

Figure 4. In vitro bacteria viability test of (A) $\mathrm{CNO}$ (black bar) and (B) $\mathrm{CNO}-\mathrm{COOH}$ (gray bar) with varying concentrations $(1562.5,3125,6250,12,500,25,000$, and 50,000 ng/mL) using colony counting assay against Escherichia coli.

\section{Summary}

To evaluate the biocompatibility of $\mathrm{CNO}$ and $\mathrm{CNO}-\mathrm{COOH}$, an in vitro cytotoxicity evaluation, immunological assays, hemolysis test, ROS production analysis, and toxicity evaluation against $E$. coli were performed. $\mathrm{CNO}$ and $\mathrm{CNO}-\mathrm{COOH}$ showed no toxicity to human HDF cells and PBMCs at concentrations below $500 \mathrm{ng} / \mathrm{mL}$. Neither CNO induced IL-2 and TNF-alpha secretion significantly. The hemolysis rate was also low, indicating that $\mathrm{CNO}$ and $\mathrm{CNO}-\mathrm{COOH}$ have blood compatibility. Neither CNO was toxic to the E. coli intestinal bacteria. The results of this study show that CNO and $\mathrm{CNO}-\mathrm{COOH}$ have excellent biocompatibility because of the low occurrence of ROS, which is believed to be the leading cause of carbon nanomaterial toxicity. CNOs are promising for future use in diverse biomedical and biomolecular engineering applications, including drug delivery, theranostics, and biosensors. In this study, conjugation of the various biomolecule is possible by functionalizing $\mathrm{COOH}$ in $\mathrm{CNO}$. For example, peptide, DNA, and protein can be attached to the $\mathrm{COOH}$ of carbon nanomaterials through EDC-NHS crosslinkers. A fluorescent dye, metal nanoparticles, or other 
non-biomolecular materials are also expected to be conjugated to $\mathrm{COOH}$ of carbon nanomaterials for further applications.

Supplementary Materials: The following are available online at http://www.mdpi.com/2079-4991/9/7/1016/s1. Figure S1. XPS spectra of $\mathrm{C} 1 \mathrm{~s}(\mathrm{~A}$ and $\mathrm{C}$ ) and $\mathrm{O} 1 \mathrm{~s}(\mathrm{~B}$ and $\mathrm{D})$ peaks of $\mathrm{CNO}(\mathrm{A}$ and $\mathrm{B}$ ) and $\mathrm{CNO}-\mathrm{COOH}(\mathrm{C}$ and D). Figure S2. Spectral survey of (A) $\mathrm{CNO}$ and (B) $\mathrm{CNO}-\mathrm{COOH}$, showing increased oxygen contents. Figure S3. (A) Fluorescent microscopic images from live and dead assay for $\mathrm{CNO}$ and $\mathrm{CNO}-\mathrm{COOH}$ with different concentrations on HDF cells after $24 \mathrm{~h}$ incubation; (B) microscopic images of PBMC after treatment of CNO and $\mathrm{CNO}-\mathrm{COOH}$ with different concentrations and after $24 \mathrm{~h}$ incubation. Table S1. Atomic composition of $\mathrm{CNO}$ and $\mathrm{CNO}-\mathrm{COOH}$. Table S2. Components of $\mathrm{CNO}$ and $\mathrm{CNO}-\mathrm{COOH}$ from $\mathrm{C} 1 \mathrm{~s}$ and $\mathrm{O} 1 \mathrm{~s}$ peaks.

Author Contributions: J.J., Y.K., Y.C., J.H., M.T., E.K., and J.C. designed the experiments. J.J., Y.K., and J.H. performed the experiments. J.J., Y.K., J.H., M.T., E.K., and J.C. analyzed the data. J.J., Y.C., E.K., and J.C. produced the figures. J.J., Y.K., E.K., and J.C. wrote the manuscript

Acknowledgments: This work was conducted with the support of the Korea Environment Industry \& Technology Institute (KEITI) through its Ecological Imitation-based Environmental Pollution Management Technology Development Project, and funded by the Korea Ministry of Environment (MOE) (Grant number: 2019002790002). This research was also supported by Chung-Ang University research grants in 2019.

Conflicts of Interest: The authors declare no conflict of interest.

\section{References}

1. Farokhzad, O.C.; Langer, R. Nanomedicine: developing smarter therapeutic and diagnostic modalities. Adv. Drug Deliv. Rev. 2006, 58, 1456-1459. [CrossRef] [PubMed]

2. Choi, J.; Tung, S.H.; Wang, N.S.; Reipa, V. Small-angle neutron scattering measurement of silicon nanoparticle size. Nanotechnology 2008, 19, 085715. [CrossRef] [PubMed]

3. Choi, J.; Lee, E.K.; Choo, J.; Yuh, J.; Hong, J.W. Micro 3D cell culture systems for cellular behavior studies: Culture matrices, devices, substrates, and in-situ sensing methods. Biotechnol. J. 2015, 10, 1682-1688. [CrossRef] [PubMed]

4. Choi, J.; Park, S.; Stojanović, Z.; Han, H.-S.; Lee, J.; Seok, H.K.; Uskoković, D.; Lee, K.H. Facile Solvothermal preparation of monodisperse gold nanoparticles and their engineered assembly of ferritin-gold nanoclusters. Langmuir 2013, 29, 15698-15703. [CrossRef] [PubMed]

5. Reipa, V.; Purdum, G.; Choi, J. Measurement of Nanoparticle Concentration Using Quartz Crystal Microgravimetry. J. Phys. Chem. B 2010, 114, 16112-16117. [CrossRef] [PubMed]

6. Nie, S.; Xing, Y.; Kim, G.J.; Simons, J.W. Nanotechnology applications in cancer. Annu. Rev. Biomed. Eng. 2007, 9, 257-288. [CrossRef] [PubMed]

7. Kim, J.; Piao, Y.; Hyeon, T. Multifunctional nanostructured materials for multimodal imaging, and simultaneous imaging and therapy. Chem. Soc. Rev. 2009, 38, 372-390. [CrossRef]

8. Sun, C.; Lee, J.S.; Zhang, M. Magnetic nanoparticles in MR imaging and drug delivery. Adv. Drug Deliv. Rev. 2008, 60, 1252-1265. [CrossRef]

9. Yang, K.; Feng, L.Z.; Liu, Z. Stimuli responsive drug delivery systems based on nano-graphene for cancer therapy. Adv. Drug Deliv. Rev. 2016, 105, 228-241. [CrossRef]

10. Hwang, J.; Lee, E.; Kim, J.; Seo, Y.; Lee, K.H.; Hong, J.W.; Gilad, A.A.; Park, H.; Choi, J. Effective delivery of immunosuppressive drug molecules by silica coated iron oxide nanoparticles. Colloid Surface B 2016, 142, 290-296. [CrossRef]

11. Morones, J.R.; Elechiguerra, J.L.; Camacho, A.; Holt, K.; Kouri, J.B.; Ramirez, J.T.; Yacaman, M.J. The bactericidal effect of silver nanoparticles. Nanotechnology 2005, 16, 2346-2353. [CrossRef] [PubMed]

12. Shadjou, N.; Hasanzadeh, M. Graphene and its nanostructure derivatives for use in bone tissue engineering: Recent advances. J. Biomed Mater. Res. A 2016, 104, 1250-1275. [CrossRef] [PubMed]

13. Gajendiran, M.; Choi, J.; Kim, S.J.; Kim, K.; Shin, H.; Koo, H.J.; Kim, K. Conductive biomaterials for tissue engineering applications. J. Ind. Eng. Chem. 2017, 51, 12-26. [CrossRef]

14. Tiwari, J.N.; Vij, V.; Kemp, K.C.; Kim, K.S. Engineered Carbon-Nanomaterial-Based Electrochemical Sensors for Biomolecules. Acs Nano 2016, 10, 46-80. [CrossRef] [PubMed]

15. Kim, Y.K.; Na, H.K.; Kim, S.; Jang, H.; Chang, S.J.; Min, D.H. One-pot synthesis of multifunctional Au@graphene oxide nanocolloid core@shell nanoparticles for Raman bioimaging, photothermal, and photodynamic therapy. Small 2015, 11, 2527-2535. [CrossRef] [PubMed] 
16. De Faria, A.F.; Martinez, D.S.T.; Meira, S.M.M.; de Moraes, A.C.M.; Brandelli, A.; Souza, A.G.; Alves, O.L. Anti-adhesion and antibacterial activity of silver nanoparticles supported on graphene oxide sheets. Colloid Surface B 2014, 113, 115-124. [CrossRef]

17. Jia, G.; Wang, H.; Yan, L.; Wang, X.; Pei, R.; Yan, T.; Zhao, Y.; Guo, X. Cytotoxicity of carbon nanomaterials: single-wall nanotube, multi-wall nanotube, and fullerene. Environ. Sci. Technol. 2005, 39, 1378-1383. [CrossRef]

18. Warheit, D.B.; Laurence, B.R.; Reed, K.L.; Roach, D.H.; Reynolds, G.A.; Webb, T.R. Comparative pulmonary toxicity assessment of single-wall carbon nanotubes in rats. Toxicol. Sci. 2004, 77, 117-125. [CrossRef]

19. Lam, C.W.; James, J.T.; McCluskey, R.; Hunter, R.L. Pulmonary toxicity of single-wall carbon nanotubes in mice 7 and 90 days after intratracheal instillation. Toxicol. Sci. 2004, 77, 126-134. [CrossRef]

20. Schrand, A.M.; Dai, L.; Schlager, J.J.; Hussain, S.M.; Osawa, E. Differential biocompatibility of carbon nanotubes and nanodiamonds. Diam. Relat. Mater. 2007, 16, 2118-2123. [CrossRef]

21. Li, Y.; Liu, Y.; Fu, Y.J.; Wei, T.T.; Le Guyader, L.; Gao, G.; Liu, R.S.; Chang, Y.Z.; Chen, C.Y. The triggering of apoptosis in macrophages by pristine graphene through the MAPK and TGF-beta signaling pathways. Biomaterials 2012, 33, 402-411. [CrossRef] [PubMed]

22. Dong, W.H.; Ren, Y.P.; Zhang, Y.Y.; Chen, Y.; Zhang, C.; Bai, Z.X.; Ma, R.; Chen, Q. Synthesis of Pb nanowires-Au nanoparticles nanostructure decorated with reduced graphene oxide for electrochemical sensing. Talanta 2017, 165, 604-611. [CrossRef] [PubMed]

23. Wan, B.; Wang, Z.X.; Lv, Q.Y.; Dong, P.X.; Zhao, L.X.; Yang, Y.; Guo, L.H. Single-walled carbon nanotubes and graphene oxides induce autophagosome accumulation and lysosome impairment in primarily cultured murine peritoneal macrophages. Toxicol. Lett. 2013, 221, 118-127. [CrossRef]

24. Zeng, Y.P.; Yang, Z.Y.; Luo, S.L.; Li, H.; Liu, C.; Hao, Y.H.; Liu, J.; Wang, W.D.; Li, R. Fast and facile preparation of PEGylated graphene from graphene oxide by lysosome targeting delivery of photosensitizer to efficiently enhance photodynamic therapy. Rsc Adv. 2015, 5, 57725-57734. [CrossRef]

25. Dong, P.X.; Wan, B.; Wang, Z.X.; Guo, L.H.; Yang, Y.; Zhao, L. Exposure of single-walled carbon nanotubes impairs the functions of primarily cultured murine peritoneal macrophages. Nanotoxicology 2013, 7, 1028-1042. [CrossRef] [PubMed]

26. Chen, B.; Liu, Y.; Song, W.M.; Hayashi, Y.; Ding, X.C.; Li, W.H. In Vitro Evaluation of Cytotoxicity and Oxidative Stress Induced by Multiwalled Carbon Nanotubes in Murine RAW 264.7 Macrophages and Human A549 Lung Cells. Biomed. Environ. Sci. 2011, 24, 593-601.

27. Wang, X.; Guo, J.; Chen, T.; Nie, H.; Wang, H.; Zang, J.; Cui, X.; Jia, G. Multi-walled carbon nanotubes induce apoptosis via mitochondrial pathway and scavenger receptor. Toxicol. In Vitro 2012, 26, 799-806. [CrossRef]

28. Chen, H.Q.; Wang, B.; Gao, D.; Guan, M.; Zheng, L.N.; Ouyang, H.; Chai, Z.F.; Zhao, Y.L.; Feng, W.Y. Broad-Spectrum Antibacterial Activity of Carbon Nanotubes to Human Gut Bacteria. Small 2013, 9, 2735-2746. [CrossRef]

29. Fernandes, A.M.; Abdalhai, M.H.; Ji, J.; Xi, B.W.; Xie, J.; Sun, J.; Noeline, R.; Lee, B.H.; Sun, X. Development of highly sensitive electrochemical genosensor based on multiwalled carbon nanotubes-chitosan-bismuth and lead sulfide nanoparticles for the detection of pathogenic Aeromonas. Biosens Bioelectron 2015, 63, 399-406. [CrossRef]

30. Zhang, X.K.; Meng, L.J.; Lu, Q.H.; Fei, Z.F.; Dyson, P.J. Targeted delivery and controlled release of doxorubicin to cancer cells using modified single wall carbon nanotubes. Biomaterials 2009, 30, 6041-6047. [CrossRef]

31. Ali, M.A.; Srivastava, S.; Solanki, P.R.; Reddy, V.; Agrawal, V.V.; Kim, C.; John, R.; Malhotra, B.D. Highly efficient bienzyme functionalized nanocomposite-based microfluidics biosensor platform for biomedical application. Sci. Rep. 2013, 3, 2661. [CrossRef] [PubMed]

32. Flavin, K.; Chaur, M.N.; Echegoyen, L.; Giordani, S. Functionalization of multilayer fullerenes (carbon nano-onions) using diazonium compounds and "click" chemistry. Org. Lett. 2010, 12, 840-843. [CrossRef] [PubMed]

33. Bartelmess, J.; Giordani, S. Carbon nano-onions (multi-layer fullerenes): chemistry and applications. Beilstein J. Nanotechnol. 2014, 5, 1980-1998. [CrossRef] [PubMed]

34. Marchesano, V.; Ambrosone, A.; Bartelmess, J.; Strisciante, F.; Tino, A.; Echegoyen, L.; Tortiglione, C.; Giordani, S. Impact of Carbon Nano-Onions on Hydra vulgaris as a Model Organism for Nanoecotoxicology. Nanomater. Basel 2015, 5, 1331-1350. [CrossRef] [PubMed] 
35. Palkar, A.; Melin, F.; Cardona, C.M.; Elliott, B.; Naskar, A.K.; Edie, D.D.; Kumbhar, A.; Echegoyen, L. Reactivity differences between carbon nano onions (CNOs) prepared by different methods. Chem-Asian J. 2007, 2, 625-633. [CrossRef]

36. Liong, M.; Lu, J.; Kovochich, M.; Xia, T.; Ruehm, S.G.; Nel, A.E.; Tamanoi, F.; Zink, J.I. Multifunctional inorganic nanoparticles for imaging, targeting, and drug delivery. Acs Nano 2008, 2, 889-896. [CrossRef]

37. Lee, S.C.; Kim, C.; Kwon, I.C.; Chung, H.; Jeong, S.Y. Polymeric micelles of poly (2-ethyl-2-oxazoline)-block-poly ( $\varepsilon$-caprolactone) copolymer as a carrier for paclitaxel. J. Controll. Release 2003, 89, 437-446.

38. Karlsson, H.L.; Cronholm, P.; Gustafsson, J.; Moller, L. Copper oxide nanoparticles are highly toxic: a comparison between metal oxide nanoparticles and carbon nanotubes. Chem. Res. Toxicol. 2008, 21, 1726-1732. [CrossRef]

39. Fritz, J.M.; Weaver, T.E. The BiP cochaperone ERdj4 is required for B cell development and function. PLoS ONE 2014, 9, e107473. [CrossRef]

40. Harwig, S.; Tan, L.; Qu, X.-D.; Cho, Y.; Eisenhauer, P.B.; Lehrer, R.I. Bactericidal properties of murine intestinal phospholipase A2. J. Clin. Investig. 1995, 95, 603-610. [CrossRef]

41. Das, S.; Singh, S.; Singh, V.; Joung, D.; Dowding, J.M.; Reid, D.; Anderson, J.; Zhai, L.; Khondaker, S.I.; Self, W.T. Oxygenated functional group density on graphene oxide: its effect on cell toxicity. Part. Part. Syst. Charact. 2013, 30, 148-157. [CrossRef]

42. Arthur, J.C.; Gharaibeh, R.Z.; Muhlbauer, M.; Perez-Chanona, E.; Uronis, J.M.; McCafferty, J.; Fodor, A.A.; Jobin, C. Microbial genomic analysis reveals the essential role of inflammation in bacteria-induced colorectal cancer. Nat. Commun. 2014, 5, 4724. [CrossRef] [PubMed]

43. Fei, N.; Zhao, L. An opportunistic pathogen isolated from the gut of an obese human causes obesity in germfree mice. ISME J. 2013, 7, 880-884. [CrossRef] [PubMed]

44. Jie, Z.; Xia, H.; Zhong, S.L.; Feng, Q.; Li, S.; Liang, S.; Zhong, H.; Liu, Z.; Gao, Y.; Zhao, H.; et al. The gut microbiome in atherosclerotic cardiovascular disease. Nat. Commun. 2017, 8, 845. [CrossRef] 